\title{
Internal Factors Affecting Commercial Bank Lending: Symmetric and Asymmetric Effects of Macro-Level Data Evidence
}

\author{
Arintoko Arintoko \\ Department of Economics and Development Studies, Faculty of Economics and Business, \\ Universitas Jenderal Soedirman, Indonesia \\ *Corresponding Author: arintoko@unsoed.ac.id
}

\begin{abstract}
The purpose of this study is to estimate the symmetric and asymmetric effects of internal factors on bank lending measured by loan to deposit ratio (LDR). The analysis model applies the Autoregressive Distributed Lag (ARDL) and nonlinear ARDL models. The data analyzed are monthly time series and cover the period of 2012M01 - 2020M06. The contribution of this research is the provision of empirical evidence of the asymmetric effect of internal bank performance on bank lending at the macro-level data. The results show that the non-performing loan (NPL) is a consistent and robust variable that has a negative effect on bank lending both in the short and long run, both symmetrically and asymmetrically. The capital adequacy ratio (CAR) positively affects bank lending when it decreases in the long run. Operating expense to operating income (OEOI) has a negative effect only in the short run, assuming symmetric and asymmetric effects. The liquid assets ratio (LAR) has a negative effect on bank lending when it increases both in the short and long run. The banking supervisory agency needs to consistently supervise and enforce regulations effectively related to bank soundness, especially those concerning increasing performing loans, strengthening the capital structure, and improving efficiency.
\end{abstract}

Keywords: ARDL model; asymmetric effect; bank lending; bank performance; bank soundness

\section{INTRODUCTION}

Banking institutions have a vital function in the economy, especially those characterized by a bank-based financial system. Indonesia is one of the countries with a financial system that still relies on the role of banks, which is indicated by the share of bank assets which are still the majority in the assets of financial institutions. In countries where the financial system still relies on banks, banking institutions have a vital role in the implementation of a sustainable financial system, and bank institutions are the main 
source of investment financing while the capital market is developing (Moradi et al., 2016).

The important role of banks is prominent in terms of the functioning of the bank as an intermediary institution. The bank mediates between the units that have a surplus of funds and the units that need funds for productive purposes. As an intermediary credit institution, the activities of commercial banks mainly focus on receiving third-party funds and providing credits, which are two main activities of banks (Nguyen et al., 2018). The ability of a bank to perform its intermediation function can be measured by the ability to provide loans relative to the total deposit that can be collected by the bank, which is commonly referred to as the loan to deposit ratio (LDR). If the LDR increases, it indicates an increase in the bank's ability to provide loans to borrowers. Along with the reliance on banks as a source of investment funding and working capital, the performance of banks in channeling credit to the business sector has become crucial.

So far, many studies related to bank loans have analyzed determinants from external factors, including research conducted by Duran and Duran (2017) and Oyebowale (2020). However, external factors are factors that the bank cannot control. Therefore, research that focuses on internal factors will be more useful in implementing strategies for increasing loan provision. Efforts to increase bank lending are possible through controlling internal factors rather than external factors. Internal factors that are expected to influence bank lending according to the literature, in general, include nonperforming loans (NPL), capital adequacy ratio (CAR), operating expenses to operating income (OEOI), and liquid assets ratio (LAR). These four factors represent sufficient explanatory variables because they include credit risk, capital capacity, bank operation efficiency, and liquidity.

However, there have also been quite a lot of studies on the internal factors determining bank loans, and some have combined them with external factors, including the study conducted by Al-Kilani and Kaddumi (2015), Alkhazaleh (2017), and Miyajima (2020). This study will focus on pure internal factors that affect bank lending as proxied by LDR.

The LDR is one of the main ratios of banks related to bank loans. The LDR is the ratio used to assess bank liquidity as a comparison of total bank loans with total deposits. The LDR is calculated by dividing the total amount of bank loans by the number of deposits in the same period. Concerning credit, the LDR can be used as an indication of the level of ability of conventional banks to channel funds originating from the public in the form of loans. So the LDR reflects how much the bank's deposits as core funds are lent to borrowers. The higher the LDR, the higher the bank loan relative to the bank deposit. The loan to deposit ratio is also often used as an indication to assess the financial soundness of a company in carrying out its business activities. Regarding the LDR, bank activities in providing loans along with deposits obtained from the public can be directly performed by the bank.

For investors, the bank's LDR provides information to them on whether the bank's operations are managed properly. For monetary policy, LDR can be used as a measure of the effectiveness of a bank lending channel. In general, LDR can be used as an indicator of bank lending with control by bank deposits, which is useful for related parties, including investors, banking supervisory institutions, central banks, and the business sector. 
Considering the importance of the role of banking for Indonesia, which is a developing country with a bank-based financial system, this research is still urgent. As an emerging country, one of the main sources of financing for investment and working capital for businesses originating from banks is still very relevant. This study is motivated to provide empirical evidence of the asymmetric effect of internal factors affecting bank lending in Indonesia. So far, many studies have assumed a symmetric effect only. This study uses macro-level data to provide clear evidence that so far, there is weak evidence from some previous studies with macro-level data, while studies with macro-level data are still limited.

This study aims to examine the effect of internal bank factors on bank lending relative to bank deposits as measured by LDR with the assumption of symmetric and asymmetric effects, and in the short and long run. The research was conducted on macrolevel data in the form of aggregate data for commercial banks in Indonesia. Internal variables include NPL, CAR, OEOI, and LAR.

\section{HYPOTHESES DEVELOPMENT}

From the perspective of the endogenous money theory, LDR can be viewed as an indicator that measures the level of credit activity in a region or country compared to its deposit base (Park \& Min, 2021). Therefore, a high LDR indicates a higher level of lending activity than deposit activities. Several internal factors are hypothesized to affect the ability of banks to provide credit.

Non-performing loans are the first factor affecting the ability of bank loan provision. The use of NPL for banks is to measure the risk of credit in addition to assessing the quality of the bank's loan portfolio (Sarath \& Pham, 2015; Singh et al., 2021). Non-performing loans refer to loans whose loan repayments are scheduled for longer than 90 days and do not provide interest income for the bank (Atoi, 2018). In general, non-performing loans will tend to move negatively towards commercial bank lending (Cucinelli, 2015). The reason is that banks with high non-performing loans tend to have riskier bank loan portfolios. Therefore banks must allocate more provisions for loan losses to protect the default risk. According to Asmara and Supardi (2019), , banks with high NPLs will hamper their credit distribution and reduce their lending to the public. An increase in NPL which means a decrease in the quality of bank assets, will adversely affect the health and efficiency of the banking sector (Zhu et al., 2015). Isa et al. (2019) found evidence that NPL negatively affects bank loans. Through a study of bank-level data, Miyajima (2020) found evidence that NPLs negatively affect bank lending. Also, the research conducted by Polizzi et al. (2020) proves that NPLs negatively and significantly affect the growth of bank credit. The theoretical logic supported by the results of previous research helps formulate the first hypothesis, which can be stated as follows:

$\mathrm{H}_{1}$ : Non-performing loan negatively affects bank lending, both symmetrically and asymmetrically

The capital adequacy ratio indicator measures the ability of a bank to fulfill its obligations. The increase in CAR informs that banks are increasingly able to absorb losses experienced without reducing capital. Miyajima (2020) finds strong evidence that capital ratios positively affect bank lending with a panel approach to bank-level data. A higher CAR creates a higher bank's ability to accommodate the risk of each risky credit so that 
the bank's ability to extend credit is higher. It is increasingly possible for banks to be able to provide additional new loans. According to Kim and Sohn (2017), bank capital positively and significantly affects loans from large banks that maintain adequate liquid assets. Also, according to Prawitasari et al. (2020), that CAR positively and significantly affects bank lending. Similarly, Polizzi et al. (2020) prove that the capital ratio positively and significantly affects the growth of bank loans. The explanation of the results of previous studies that prove the logic of the theory supports the formulation of the following second hypothesis:

$\mathrm{H}_{2}$ : Capital adequacy ratio positively affects bank lending, both symmetrically and asymmetrically

The OEOI ratio is the ratio between operating expenses and operating income which can be used as a measure of the efficiency of bank operations. This measure has been used in several previous studies, including studies conducted by Iskandar (2017) and Mujiatun and Handayani (2018). Lower OEOI means more efficient bank operations. The more efficient bank operations will improve the bank's ability to provide bank lending with lower credit costs. Therefore, the more efficient the bank, the more banks can provide bank lending. Mirzaei and Moore (2019) found strong evidence that bank efficiency affects the increase in external funding to increase growth and market structure in the manufacturing sector. This is due to increased bank efficiency, which can increase the ability of banks to provide bank lending.

Improved bank efficiency encourages lower mark-up charges so as to lower loan interest rates for borrowers (Havranek et al., 2016). A reduction in borrowing costs may be able to encourage loan demand (Naceur et al., 2018). The hypothesis of Shamshur and Weill (2019) states that bank efficiency is synonymous with lower loan interest rates so that it can reduce the cost of credit. This efficiency reflects the ability of banks to conduct operations at lower costs. Shamshur and Weill (2019) find evidence that increased bank efficiency tends to lead to lower costs of credit. Especially for SMEs, increasing efficiency reduces the cost of credit.

Overall, the results show that increasing bank efficiency can encourage bank credit access. It can be concluded that OEOI negatively affects bank lending. The increase in OEOI indicates that bank operations are increasingly inefficient. Therefore, banks' ability to provide credit will decrease. Conclusions from empirical findings and theoretical logic underlie the formulation of the following third hypothesis:

$\mathrm{H}_{3}$ : Operating expense to operating income ratio negatively affects bank lending, both symmetrically and asymmetrically

The bank's liquidity reflects the bank's ability in its operations to convert short-term assets into cash but with the possibility of obtaining minimal losses. In this case, the level of bank liquidity can measure the effect of the proportional liquid assets owned by the bank on lending. According to Rabab'ah (2015), increasing liquidity in banks will weaken the ability of banks to provide loans to borrowers. This negative relationship is empirically proven by research conducted by Moussa and Chedia (2016) and Adzis et al. (2018). Their studies provide strong evidence that the level of bank liquidity will have a negative impact on their lending behavior. The rationale of the relationship in theory which is supported by empirical evidence, underlies the formulation of the following fourth hypothesis: 
$\mathrm{H}_{4}$ : Liquidity asset ratio negatively affects bank lending, both symmetrically and asymmetrically

\section{METHOD, DATA, AND ANALYSIS}

\section{Research Method}

This study is a correlational study that aims to analyze the effect of the variables of the bank's performance ratio on bank loans as measured by LDR. Hypothesis testing is carried out based on secondary data obtained from the Financial Services Authority. The data used are macro-level data, namely the national aggregate data for conventional banks in Indonesia. The analytical model used in testing the hypothesis is the ARDL model, which can be used to analyze the relationship between variables in the short and long run.

The ARDL model has been popular and widely used especially in economics and business research. The use of the ARDL model in financial studies has been widely used, for example, in the study conducted by Baoko et al. (2017), Qamruzzaman and Wei (2018), and Arintoko (2021). Furthermore, the ARDL model develops into a nonlinear ARDL, which assumes an asymmetric effect between variables. The nonlinear ARDL model used is the model that has been applied by Bahmani-Oskooee and Fariditavana (2015). Compared to the ARDL model, the application of the nonlinear ARDL model is still relatively limited, especially in studies of finance. Therefore, this study is motivated to apply the nonlinear ARDL model in the analysis of the asymmetric effect of internal factors on bank lending. However, the effect of a variable on other variables is not always symmetric between when it is increasing and when it is decreasing. The significant effect can only occur when it is increasing or when it is decreasing.

\section{Data and Variables}

Internal factors that are predicted to affect bank lending are viewed from the aspects of credit risk, capital capacity, the efficiency of bank operations, and liquidity. These four aspects are each represented by NPL, CAR, OEOI, and LAR as independent variables. Meanwhile, the dependent variable is bank lending, which is proxied by the LDR. Data for all variables are accessed from the Financial Services Authority (OJK).

The loan to deposit ratio in this study is used to measure bank lending relative to bank deposits in addition to showing bank liquidity. The loan to deposit ratio (LDR) is measured by the ratio of the total loan to the total deposit. The ratio measure is expressed as a percentage.

A non-performing loan (NPL) is a loan when borrowers are in default because they have not made scheduled payments for a certain period. A commercial loan is considered non-performing if the borrower is unable to make payments for up to 90 days past the due date. The International Monetary Fund considers loans with a due date of fewer than 90 days as non-performing if there is high uncertainty about future payments.

The capital adequacy ratio (CAR) is the ratio of bank capital to risk-weighted assets. Bank capital consists of tier 1 and tier 2 capital. Tier 1 capital includes equity capital, common share capital, intangible assets, and audited reserves for income. Tier 2 capital is capital that refers to one of the components of the reserve required by the bank. Calculation of risk-weighted assets by looking at bank loans, evaluating risks, and then 
assigning weights. Credit exposure is measured by adjustments made to the value of assets listed on a lender's balance sheet.

The operating expenses to operating income (OEOI) ratio can clearly measure a bank's operational efficiency. The operating expense to operating income ratio is calculated as the ratio between operating expenses and operating income and is expressed as a percentage. The decreasing OEOI shows the more efficient the bank is and the more profitable it is for the bank. Conversely, the increasing OEOI indicates the more inefficient banks are in operating.

The liquid assets ratio (LAR) is the ratio of primary liquid assets plus secondary liquid assets to the bank's total assets. This ratio is expressed in percentage terms. The liquid asset ratio can also be interpreted as the ratio of assets that can be easily converted to money to total bank assets. Therefore this ratio can be used to measure bank liquidity associated with bank assets. If the greater the ratio of liquid assets, the higher the liquidity of the bank.

The data studied are aggregate data for commercial banks. The data obtained from the Financial Services Authority are monthly data for the period of January 2012 to June 2020. These data are analyzed to test the proposed hypotheses.

\section{Model of ARDL and Nonlinear ARDL}

The ARDL model in this study is applied to investigate the effect of NPL, CAR, OEOI, and LAR on bank lending proxied by LDR, assuming an asymmetric effect. The model developed refers to Arintoko (2021). The model developed is written in equation (1).

$\Delta \mathrm{LDR}_{\mathrm{t}}=\alpha+\beta \mathrm{LDR}_{\mathrm{t}-1}+\delta_{1} \mathrm{NPL}_{\mathrm{t}-1}+\delta_{2} \mathrm{CAR}_{\mathrm{t}-1}+\delta_{3} \mathrm{OEOI}_{\mathrm{t}-1}+\delta_{4} \mathrm{LAR}_{\mathrm{t}-1}+$
$\sum_{\mathrm{i}=1}^{\mathrm{m}-1} \gamma_{\mathrm{i}} \Delta \mathrm{LDR}_{\mathrm{t}-\mathrm{i}}+\sum_{\mathrm{i}=0}^{\mathrm{n}-1} \lambda_{\mathrm{i}} \Delta \mathrm{NPL}_{\mathrm{t}-\mathrm{i}}+\sum_{\mathrm{i}=0}^{\mathrm{p}-1} \varphi_{\mathrm{i}} \Delta \mathrm{CAR}_{\mathrm{t}-\mathrm{i}}+\sum_{\mathrm{i}=0}^{\mathrm{q}-1} \rho_{\mathrm{i}} \Delta \mathrm{OEOI}_{\mathrm{t}-\mathrm{i}}+\sum_{\mathrm{i}=0}^{\mathrm{r}-1} \phi_{\mathrm{i}} \Delta \mathrm{LAR}_{\mathrm{t}-\mathrm{i}}+$
$\varepsilon_{\mathrm{t}}$

Expected long-run coefficients:

$$
-\frac{\delta_{1}}{\beta}<0,-\frac{\delta_{2}}{\beta}>0,-\frac{\delta_{3}}{\beta}<0,-\frac{\delta_{4}}{\beta}<0
$$

An estimate of the effect was carried out by separating the effect of the independent variable to investigate further. The model applied is the model used by Bahmani-Oskooee and Fariditavan (2015). Furthermore, the ARDL model in equation (1) is developed to estimate the asymmetric effect into equation (2).

$$
\begin{aligned}
& \Delta \mathrm{LDR}_{\mathrm{t}}=\alpha+\beta \mathrm{LDR}_{\mathrm{t}-1}+\delta_{1}^{+} \mathrm{NPL}_{\mathrm{t}-1}^{+}+\delta_{1}^{-} \mathrm{NPL}_{\mathrm{t}-1}^{-}+\delta_{2}^{+} \mathrm{CAR}_{\mathrm{t}-1}^{+}+\delta_{2}^{-} \mathrm{CAR}_{\mathrm{t}-1}^{-}+\delta_{3}^{+} \mathrm{OEOI}_{\mathrm{t}-1}^{+}+ \\
& \delta_{3}^{-} \mathrm{OEOI}_{\mathrm{t}-1}^{-}+\delta_{4}^{+} \mathrm{LAR}_{\mathrm{t}-1}^{+}+\delta_{4}^{-} \mathrm{LAR}_{\mathrm{t}-1}^{-}+\sum_{\mathrm{i}=1}^{\mathrm{m}-1} \gamma_{\mathrm{i}} \Delta \mathrm{LDR}_{\mathrm{t}-\mathrm{i}}+\sum_{\mathrm{i}=0}^{\mathrm{n}-1}\left(\lambda_{\mathrm{i}}^{+} \Delta \mathrm{NPL}_{\mathrm{t}-\mathrm{i}}^{+}+\lambda_{\mathrm{i}}^{-} \Delta \mathrm{NPL}_{\mathrm{t}-\mathrm{i}}^{-}\right)+ \\
& \sum_{\mathrm{i}=0}^{\mathrm{p}-1}\left(\varphi_{\mathrm{i}}^{+} \Delta \mathrm{CAR}_{\mathrm{t}-\mathrm{i}}^{+}+\varphi_{\mathrm{i}}^{-} \Delta \mathrm{CAR}_{\mathrm{t}-\mathrm{i}}^{-}\right)+\sum_{\mathrm{i}=0}^{\mathrm{q}-1}\left(\rho_{\mathrm{i}}^{+} \Delta \mathrm{OEOI}_{\mathrm{t}-\mathrm{i}}^{+}+\rho_{\mathrm{i}}^{-} \Delta \mathrm{OEOI}_{\mathrm{t}-\mathrm{i}}^{-}\right)+\sum_{\mathrm{i}=0}^{\mathrm{r}-1}\left(\phi_{\mathrm{i}}^{+} \Delta \mathrm{LAR}_{\mathrm{t}-\mathrm{i}}^{+}+\right. \\
& \left.\phi_{\mathrm{i}}^{-} \Delta \mathrm{LAR}_{\mathrm{t}-\mathrm{i}}^{-}\right)+\varepsilon_{\mathrm{t}}
\end{aligned}
$$

Where:

$$
\begin{array}{r}
\mathrm{NPL}_{\mathrm{t}}^{+}=\sum_{\mathrm{j}=1}^{\mathrm{t}} \Delta \mathrm{NPL}_{\mathrm{j}}^{+}=\sum_{\mathrm{j}=1}^{\mathrm{t}} \max \left(\Delta \mathrm{NPL}_{\mathrm{j}}, 0\right) \\
\mathrm{NPL}_{\mathrm{t}}^{-}=\sum_{\mathrm{j}=1}^{\mathrm{t}} \Delta \mathrm{NPL}_{\mathrm{j}}^{-}=\sum_{\mathrm{j}=1}^{\mathrm{t}} \min \left(\Delta \mathrm{NPL}_{\mathrm{j}}, 0\right) \\
\mathrm{CAR}_{\mathrm{t}}^{+}=\sum_{\mathrm{j}=1}^{\mathrm{t}} \Delta \mathrm{CAR}_{\mathrm{j}}^{+}=\sum_{\mathrm{j}=1}^{\mathrm{t}} \max \left(\Delta \mathrm{CAR}_{\mathrm{j}}, 0\right)
\end{array}
$$




$$
\begin{aligned}
& \mathrm{CAR}_{\mathrm{t}}^{-}=\sum_{\mathrm{j}=1}^{\mathrm{t}} \Delta \mathrm{CAR}_{\mathrm{j}}^{-}=\sum_{\mathrm{j}=1}^{\mathrm{t}} \min \left(\Delta \mathrm{CAR}_{\mathrm{j}}, 0\right) \\
& \mathrm{OEOI}_{\mathrm{t}}^{+}=\sum_{\mathrm{j}=1}^{\mathrm{t}} \Delta \mathrm{OEOI}_{\mathrm{j}}^{+}=\sum_{\mathrm{j}=1}^{\mathrm{t}} \max \left(\Delta \mathrm{EEOI}_{\mathrm{j}}, 0\right) \\
& \mathrm{OEOI}_{\mathrm{t}}^{-}=\sum_{\mathrm{j}=1}^{\mathrm{t}} \Delta \mathrm{OEOI}_{\mathrm{j}}^{-}=\sum_{\mathrm{j}=1}^{\mathrm{t}} \min \left(\Delta \mathrm{OEOI}_{\mathrm{j}}, 0\right) \\
& \mathrm{LAR}_{\mathrm{t}}^{+}=\sum_{\mathrm{j}=1}^{\mathrm{t}} \Delta \mathrm{LAR}_{\mathrm{j}}^{+}=\sum_{\mathrm{j}=1}^{\mathrm{t}} \max \left(\Delta \mathrm{LAR}_{\mathrm{j}}, 0\right) \\
& \mathrm{LAR}_{\mathrm{t}}^{-}=\sum_{\mathrm{j}=1}^{\mathrm{t}} \Delta \mathrm{LAR}_{\mathrm{j}}^{-}=\sum_{\mathrm{j}=1}^{\mathrm{t}} \min \left(\Delta \mathrm{LAR}_{\mathrm{j}}, 0\right)
\end{aligned}
$$

Expected long-run coefficients:

$$
\begin{aligned}
& -\frac{\delta_{1}^{+}}{\beta}<0,-\frac{\delta_{1}^{-}}{\beta}<0,-\frac{\delta_{1}^{+}}{\beta} \neq-\frac{\delta_{1}^{-}}{\beta} \\
& -\frac{\delta_{2}^{+}}{\beta}>0,-\frac{\delta_{2}^{-}}{\beta}>0,-\frac{\delta_{2}^{+}}{\beta} \neq-\frac{\delta_{2}^{-}}{\beta} \\
& -\frac{\delta_{3}^{+}}{\beta}<0,-\frac{\delta_{3}^{-}}{\beta}<0,-\frac{\delta_{3}^{+}}{\beta} \neq-\frac{\delta_{3}^{-}}{\beta} \\
& -\frac{\delta_{4}^{+}}{\beta}<0,-\frac{\delta_{4}^{-}}{\beta}<0,-\frac{\delta_{4}^{+}}{\beta} \neq-\frac{\delta_{4}^{-}}{\beta}
\end{aligned}
$$

Estimation coefficients in the expected model as in the equation both in the ARDL and nonlinear ARDL models are based on the logic of the relationship between variables in the previous development of the hypothesis. Equation (1) is an ARDL model that will be estimated assuming symmetric effect, while equation (2) is a nonlinear ARDL model. that is estimated assuming asymmetric effect to get the best model from the ARDL model, the Akaike info criterion (AIC) selection method is used. Meanwhile, to obtain the best model from the nonlinear ARDL model, the stepwise least squares method is used. Both models were tested to identify possible long-run relationships based on the bound test as performed.

Before estimating through the application of the ARDL model, the properties of the data series are tested to identify the unit roots of each series. This test expects that the dependent variable is stationary in the first difference, while the independent variables can be stationary at both the level and the first difference so that the ARDL model can be applied, referring to Baoko et al. (2017).

\section{RESULTS}

\section{Descriptive Statistics}

This section begins with a description of the statistical data analyzed. Table 1 shows that the LDR, which measures bank lending relative to its deposit, has a range of 78.58 percent to 96.19 percent. Generally, the ideal LDR is 80 percent to 90 percent. If the ratio reaches 100 percent, the bank lends one rupiah to the customer for every rupiah it receives from its savings. However, the current provision of Bank Indonesia sets a safe limit for LDR in the range of 78 percent to 92 percent.

The consequence of the LDR that exceeds the upper limit is a penalty from Bank Indonesia in the form of an additional deposit from the statutory reserve requirement (GWM) for every one percent excess of the safe limit of the LDR. Therefore, the excess of the LDR from the safe limit must be balanced with an excess of capital adequacy ratio above 14 percent. 
However, overall, the bank has met the lower limit of the safe LDR range because the minimum LDR is 78.58 percent, and the average LDR is also in the safe limit with an average of 89.43 percent. In general, the range of the LDR can still be considered moderate and ideal in line with the increase in CAR.

Table 1. Descriptive Statistics

\begin{tabular}{ccccc}
\hline Variable & Minimum & Maximum & Mean & $\begin{array}{c}\text { Standard } \\
\text { Deviation }\end{array}$ \\
\hline LDR & 78.58 & 96.19 & 89.43 & 3.66 \\
NPL & 1.77 & 3.22 & 2.54 & 0.40 \\
CAR & 17.28 & 23.93 & 21.14 & 2.07 \\
OEOI & 73.74 & 91.78 & 79.60 & 3.60 \\
LAR & 14.21 & 21.27 & 16.96 & 1.42 \\
\hline
\end{tabular}

During the research period, non-performing loans of commercial banks ranged from 1.77 percent to 3.22 percent, with an average of 2.54 percent. The maximum NPL, in this case, is still below the maximum NPL requirement of 5 percent. In aggregate, this NPL range shows a fairly safe credit risk from the applicable NPL maximum limit.

During the study period, the capital adequacy ratio averaged 21.14, which is a high enough CAR for an adequate capital structure as it is far above the minimum requirement of 14 percent. The minimum CAR in this study is 17.28 percent which is also above the minimum CAR required. During the analysis period, there was a tendency for CAR to increase, which is a positive indication for banking in Indonesia.

Although the OEOI in this study period ranged from 73.74 percent to 91.78 percent, the average OEOI was 79.60 percent. This average shows a value smaller than the maximum limit of OEOI, which is 85 percent. However, if OEOI exceeds 85 percent, consequently, banks will be prohibited from expanding their business. This needs to be emphasized considering that OEOI in Indonesia is still higher than in neighboring countries in ASEAN. During the research period, the OEOI of banks also tended to increase until the end of the period.

During the study period, the liquid asset ratio showed fluctuation but tended to rise again until the end of the period. The liquid asset ratio ranged from 14.21 percent to 21.27 percent. The average LAR is 16.96 percent. This ratio is important because it determines the ability in liquidity to meet liquidity needs over the next 30 day period.

\section{Unit Root Tests}

Next, data analysis related to the model begins with unit root testing of the variables used in the model to determine data stationarity. The stationary data series determines the order of integration and determines whether the regressand is $I(1)$, and the regressors are $\mathrm{I}(0)$ purely, I(1) purely, or mixed. This condition determines the suitability of using the ARDL model. The test results in this study used the Dickey-Fuller Generalized Least Squares (DF-GLS) test developed by Elliott et al. (1996). The advantage of the DF-GLS test is that it is higher power than the Augmented Dickey-Fuller (ADF) test if the autoregressive root is large and less than one.

The unit root test results are presented in Table 2. The unit root test results show that the LDR, CAR, and LAR series are I(1), while NPL and OEOI are I(0). The order of integration of these variables fulfills the requirements for the application of the ARDL model where the dependent variable is I(1) and the regressors are mixed of $\mathrm{I}(0)$ and I(1). 
Table 2. Unit Root Tests

\begin{tabular}{lll}
\hline \multirow{2}{*}{ Variables } & \multicolumn{2}{c}{ DF-GLS } \\
\cline { 2 - 3 } & Level & \multicolumn{1}{c}{ First Difference } \\
\hline LDR & -1.0334 & $-9.8392^{* * *}$ \\
NPL & $-4.3124^{* * *}$ & -1.0221 \\
CAR & -1.3914 & $-10.1976^{* * *}$ \\
OEOI & $-2.1369^{* *}$ & -1.6009 \\
LAR & -1.6337 & $-10.4238^{* * *}$ \\
\hline$* * *$ & significant at $p$-value of 0.01 and ${ }^{* *}$ significant at $p$-value of 0.05 &
\end{tabular}

\section{ARDL Model with Short-Run and Long-Run Parameters}

The best model obtained from the data analysis performed is the $\operatorname{ARDL}(1,1,4,2,1)$ model. The diagnostic test results for the model are reported in Table 3. This model has passed the problems of non-normality, multicollinearity, heteroscedasticity, and instability. Likewise, the bound test also proves that there is a long-run relationship between LDR and regressor, including NPL, CAR, OEOI, and LAR. Therefore, this model can be identified for the long-run and error correction regression for short-run parameter estimation.

Table 3. Diagnostic Checks of ARDL Model Estimation with Bounds Test

\begin{tabular}{|c|c|c|}
\hline Elements & Stat. Value & Conclusion \\
\hline $\mathrm{R}^{2}$ & 0.9592 & \\
\hline Adjusted R2 & 0.9529 & \\
\hline F-Stat & $151.9318^{* * *}$ & Significant at $p$-value of 0.01 \\
\hline Akaike Info. Criterion & 2.2046 & \\
\hline Schwarz Info. Criterion & 2.5739 & \\
\hline Jarque-Bera Stat & 4.0099 & \\
\hline LM test F-stat $(4,80)$ & 0.5824 & \\
\hline Het. test F-stat $(13,84)$ & 1.4913 & \\
\hline CUSUM Test & & Stable \\
\hline F-stat (Bound test) & $5.2376^{* * *}$ & $\begin{array}{l}\text { Reject Ho and there is a long-run } \\
\text { relationship with critical values at p- } \\
\text { value of } 0.01: \mathrm{I}(0)=3.74 \text { and } \mathrm{I}(1)=5.06\end{array}$ \\
\hline
\end{tabular}

The estimation results for long-run parameters obtained from long-run relationships in the ARDL model are reported in Table 4. With a p-value of 0.05 , the estimation results from the NPL show significant parameters and signs that are following the hypothesis. NPLs have a significant negative relationship with the bank's loan to deposit ratio in the long run. Symmetrically, if the NPL increases, it will encourage banks to reduce their loans relative to deposits so that the LDR falls, and vice versa. Higher NPL means higher default risk, which encourages banks to reduce loans, thereby reducing their LDR. The quality of existing credit affects lending decisions for banks. Conversely, the lower the NPL indicates the better quality of existing credit, which encourages banks to make decisions to increase their loans. 
Table 4. Long-Run Parameters

\begin{tabular}{lcccl}
\hline Regressor & Parameter & Std. Err. & t-stat. & \multicolumn{1}{c}{ Conclusion } \\
\hline NPL & $-2.8425^{* *}$ & 1.3413 & -2.1193 & $\begin{array}{l}\text { The hypothesis of } \mathrm{H}_{1} \\
\text { proven }\end{array}$ \\
CAR & $1.1564^{* * *}$ & 0.2220 & 5.2095 & $\begin{array}{l}\text { Hypothesis of } \mathrm{H}_{2} \text { proven } \\
\text { OEOI }\end{array}$ \\
$0.2226^{* *}$ & 0.1075 & 2.0711 & $\begin{array}{l}\text { Hypothesis of } \mathrm{H}_{3} \text { not } \\
\text { proven }\end{array}$ \\
LAR & $-1.3925^{* * *}$ & 0.2057 & -6.7694 & Hypothesis of $\mathrm{H}_{4}$ proven \\
\hline${ }^{* * *}$ significant at $p$-value of $0.01,{ }^{* *}$ significant at $p$-value of 0.05, and * significant at $p$-value 0.10
\end{tabular}

Another important finding is that a p-value of 0.01 CAR positively and significantly affects bank loans as measured by LDR. Symmetrically, the increasing capital ratio will improve the ability of the bank to supply credit so that the LDR increases, and vice versa. These results indicate the importance of an adequate capital structure in increasing the ability of banks to extend credit in enhancing the intermediation function of banks and supporting investment and production activities in the economy.

Statistically, with a p-value of 0.05 , the parameter estimation results indicate that OEOI is significant. However, the sign obtained is not following the hypothesis. The positive estimation parameter means a positive effect of operating expenses on the operating income ratio on bank loans. However, theoretically, this relationship is not as expected. This relationship does not indicate theoretical logic but simply because there is a concomitant movement between OEOI and LDR.

The results also show that the liquid asset ratio is statistically significant, and the sign obtained is as expected based on theoretical logic. So overall, the estimation results of the long-run form of the ARDL model with the assumption of symmetrical effects show that NPL, CAR, and LAR have a significant relationship with LDR with signs that are following the logic of the theory.

The results of the short-run model estimates are reported in Table 5. In the short run, NPL has a negative effect on bank loans as measured by the LDR. With a p-value of 0.01 , statistically, the estimation results of the model show evidence of a negative effect of NPL on LDR. These results indicate the consistency of the negative effects of NPLs on LDR both in the short and long run. These results provide evidence that credit quality in the short and long run is a key factor in influencing a bank's ability to provide loans to borrowers.

Table 5. Summary of ARDL Error Correction Estimation and Short-Run Parameters

\begin{tabular}{|c|c|c|c|c|}
\hline Regressor & $\mathbf{k}$ & $\begin{array}{c}\text { Sort-Run } \\
\text { Parameter }\end{array}$ & $\begin{array}{l}\text { Wald t- } \\
\text { stat }\end{array}$ & Conclusion \\
\hline $\mathrm{C}$ & & $31.6881^{* * *}$ & & \\
\hline$\sum_{i=0}^{k-1} \lambda_{j} \Delta N P L_{t-i}$ & 1 & $-2.7614^{* * *}$ & & Hypothesis of $\mathrm{H}_{1}$ proven \\
\hline$\sum_{i=0}^{k-1} \varphi_{j} \Delta C A R_{t-i}$ & 4 & -0.4933 & -1.3218 & Hypothesis of $\mathrm{H}_{2}$ not proven \\
\hline$\sum_{i=0}^{k-1} \rho_{j} \Delta O E O I_{t-i}$ & 2 & -0.1758 & $-2.7278^{* * *}$ & Hypothesis of $\mathrm{H}_{3}$ proven \\
\hline$\sum_{i=0}^{k-1} \phi_{j} \Delta L A R_{t-i}$ & 1 & $-0.8182^{* * *}$ & & Hypothesis of $\mathrm{H}_{4}$ proven \\
\hline$\overline{E C T_{t-1}}$ & & $-0.4036^{* * *}$ & & Support the expected sign \\
\hline
\end{tabular}


In the short run, there is no effect of CAR on LDR. The Wald test showed no significant t-statistical results. So in the short run, the results show no evidence of the effect of CAR on LDR. The effect of CAR on LDR is only evident in the long run.

Meanwhile, OEOI significantly affects LDR in the short run. Symmetrically, OEOI negatively affects bank loans as measured by LDR. Increased OEOI lowers bank LDR, which shows that the more inefficient the bank's operations are, the lower the bank's ability to provide loans to borrowers and vice versa. This result is following the theoretical expectation. The operating expense to operating income ratio in this study is proven to affect LDR only in the short run and not in the long run.

The estimation results of the short-run model also found that the liquid asset ratio has a significant effect on LDR with a sign that is in line with expectations. Thus, LAR negatively affects bank lending as measured by LDR according to theoretical expectations. Both in the short and long run, LAR negatively affects LDR. Overall, in the short run, the NPL, OEOI, and LAR variables negatively affect LDR. Meanwhile, assuming symmetric effect, NPL and LAR are consistent with a significant negative effect on LDR.

\section{Nonlinear ARDL and Short-Run and Long-Run Effects}

However, the results obtained in the estimation of the ARDL model in both the short and long run are assumed to be symmetrical effects. Furthermore, in this study, the effect of NPL, CAR, OEOI, and LAR on LDR can be investigated through the nonlinear ARDL model.

The diagnostic check results for the nonlinear ARDL model reached conclusions that were as good as the ARDL model. As reported in Table 6, the estimation results of the nonlinear ARDL model passed from problems related to non-normality, autocorrelation, heteroscedasticity, and non-stability models. The bond test on the nonlinear ARDL model also proves the existence of a cointegrated relationship between the variables analyzed in the model.

Table 6. Diagnostic Checks of NARDL Model Estimation and Bounds Test

\begin{tabular}{lll}
\hline Elements & Stat. Value & Conclusion \\
\hline $\mathrm{R}^{2}$ & 0.6245 & \\
Adjusted R & 0.5109 & \\
F-Stat & $5.4958^{* * *}$ & Significant at $p$-value of 0.01 \\
Akaike Info. Criterion & 2.1430 & \\
Schwarz Info. Criterion & 2.7682 & \\
Jarque-Bera Stat & 3.3394 & \\
LM test F-stat $(2,74)$ & 1.0098 & \\
Het. test F-stat $(23,76)$ & 1.2450 & \\
CUSUM Test & & Stable \\
F-stat (Bound test) & $4.0811^{* * *}$ & Reject Ho and there is a long-run \\
& & relationship with critical values at p- \\
& & value of $0.01: \mathrm{I}(0)=2.62$ and $\mathrm{I}(1)=$ \\
\end{tabular}

Table 7 reports a summary of the asymmetric effects in both the short and long run. In the short run, an asymmetric effect was found on the effect of NPL on LDR. The Wald test proves this asymmetric effect. NPLs negatively affect bank loans when NPLs increase, while when NPLs decrease NPLs do not significantly affect bank loans. So, 
when the NPL increases, it has a negative effect on the LDR. When the NPL increases, the LDR decreases, while when the NPL decreases, there is no significant effect on the LDR. When the $\triangle \mathrm{NPL}$ increases by one percent, the $\triangle \mathrm{LDR}$ will decrease by 6.11 percent. Meanwhile, CAR negatively and significantly affects bank loans when CAR decreases, so this effect is not in line with theoretical expectations.

Table 7. Summary of Asymmetric Effects Estimation

\begin{tabular}{llccc}
\hline Regressor & $\begin{array}{l}\text { Short-Run } \\
\text { Parameter }\end{array}$ & $\begin{array}{c}\text { Wald t-stat for } \\
\text { Short-Run Effect }\end{array}$ & $\begin{array}{c}\text { Long-Run } \\
\text { Parameter }\end{array}$ & $\begin{array}{c}\text { Wald t-stat for } \\
\text { Long-Run Effect }\end{array}$ \\
\hline $\mathrm{NPL}^{+}$ & $-6.1073^{* *}$ & $-1.9328^{*}$ & $-9.2590^{* *}$ & $-1.8632^{*}$ \\
$\mathrm{NPL}^{-}$ & 0.0058 & & 3.3194 & \\
$\mathrm{CAR}^{+}$ & 0.6033 & $2.8242^{* * *}$ & 0.4408 & -1.3098 \\
$\mathrm{CAR}^{-}$ & $-0.1671^{* * *}$ & & $2.6251^{* *}$ & \\
$\mathrm{OEOI}^{+}$ & $-0.2641^{* * *}$ & $3.5304^{* * *}$ & $0.6872^{*}$ & -0.2651 \\
$\mathrm{OEOI}^{-}$ & $0.1688^{*}$ & & $0.7514^{*}$ & \\
$\mathrm{LAR}^{+}$ & $-1.3977^{* * *}$ & $-2.0429^{* *}$ & $-1.7378^{* * *}$ & -1.4549 \\
LAR $^{-}$ & $-0.4028^{*}$ & & -0.0021 & \\
\hline
\end{tabular}

*** significant at $p$-value of 0.01 ** significant at $p$-value of 0.05 and * significant at $p$-value of 0.10

Asymmetric effects were also found on the effect of OEOI on LDR in the short run. When OEOI increases, it has a significant negative effect on LDR. When $\triangle$ OEOI increases by one percent, the $\Delta$ LDR will decrease by 0.26 percent. The decrease in bank efficiency will reduce the ability of banks to provide loans to borrowers.

In addition, the ratio of liquid assets negatively and significantly affects bank lending as measured by the LDR as expected theoretically. An increase in $\triangle$ LAR by one percent reduces $\Delta$ LDR by 1.40 percent. Meanwhile, decreasing $\Delta$ LAR increases $\Delta$ LDR by 0.40 percent. So the effect of increasing LAR is greater than the effect of decreasing LAR on LDR in the short run.

In the long run, NPL also has a significant negative effect on LDR. When the NPL increases by one percent, the LDR will decrease by 9.26 percent, while when the NPL decreases, there is no effect on LDR. The Wald test shows this asymmetric effect with a pvalue of 0.1 . An increase in NPL, which indicates a decline in credit quality, will reduce bank loans to borrowers so that the LDR will decrease.

Meanwhile, in the long run, there is no evidence of the asymmetric effect of other variables. However, the study results show that CAR positively and significantly affects bank lending when CAR decreases; while CAR increases, CAR does not significantly affect bank lending. A decrease in CAR by one percent will lower the LDR by 2.62 percent. Reduced capital capacity will reduce the ability of banks to provide loans.

On the other hand, OEOI does not significantly affect LDR in the long run, and this result does not match theoretical expectations. Meanwhile, LAR negatively affects LDR. This result can be interpreted that increasing the LAR by one percent reduces the LDR by 1.74 percent. Therefore, in the long run, NPL, CAR, and LAR significantly affect bank lending as measured by LDR in the estimation of the nonlinear ARDL model. 


\section{DISCUSSION}

The results of this study are important findings from the macro-level data and differ from the results of previous studies. Variables of NPL and CAR are the main internal factors that affect negatively and positively, respectively, bank loans. Meanwhile, a previous study conducted by Yasnur and Kurniasih (2017) has proven that NPL has a positive influence, while CAR does not significantly affect bank credit growth. So the findings of this study do not match their results.

However, the findings of this study are consistent with the results of a study conducted by Zulkifli et al. (2018) based on firm-level data. This finding is also in line with the results of Cucinelli (2015), Miyajima (2020), and Polizzi et al. (2020) that NPL negatively affects bank loans. So, the NPL negatively affects bank loans. Increasing NPL reduces the ability of banks to manage credit risk, thereby reducing their lending. Banks also need to allocate a high proportion of allowance for credit losses to restrict potential losses in this situation. The NPL provision does reduce bank lending, but it is important to maintain financial stability. In addition, greater public trust in the banking system will also help attract deposits from third parties and support the supply of credit.

Meanwhile, CAR positively affects bank loans. These results are consistent with the findings of research conducted by Prawitasari et al. (2020) and Polizzi et al. (2020) that CAR has a significant positive effect on bank credit provision. These results are also in line with the findings of a study conducted by Miyajima (2020), which found strong evidence that the capital ratio positively affects bank lending. The higher the CAR, the better the bank's ability to accommodate the risk of each risky credit so that the bank is more able to provide credit. The increase in CAR will give banks the ability to expand new loans. The findings of this study match the results of Kim and Sohn (2017) stated that bank capital positively affects bank lending.

On the other hand, the findings of this study do not agree with the results of the study conducted by Zulkifli et al. (2018) because OEOI has no significant effect on bank loans. However, this study, based on data at the macro level, finds evidence of the negative effect of OEOI on bank lending. An increase in OEOI means a decrease in bank efficiency, thereby reducing the bank's ability to supply loans. However, the findings of this study contradict the findings of Nguyen and Dang (2020) that bank efficiency has a positive effect on bank lending. This tendency is due to moral hazard incentives in aggressive lending strategies when efficiency decreases.

The results of the study found that the level of bank liquidity has a negative effect on bank lending. These results are in line with the findings of Rabab'ah (2015), Moussa and Chedia (2016), Adzis et al. (2018), Bhattarai (2020), and Nguyen and Dang (2020). On the other hand, these results are not in line with Isa et al. (2019) and Polizzi et al. (2020), which found a positive effect of liquidity on the bank loan. However, the bank's higher liquidity asset ratio will reduce bank lending as measured by the LDR without moral hazard from the bank's decision.

Finally, the estimation results of the nonlinear ARDL model found new evidence of the asymmetric effects of NPL, CAR, OEOI, and LAR on bank loans in the short run. Meanwhile, significant evidence of the asymmetric effect of NPLs on bank lending is also found in the long run. These findings are important results that have not been obtained from previous studies that are used as references for this study. 


\section{CONCLUSION, LIMITATIONS, AND SUGGESTIONS}

Symmetrically, CAR positively affects bank lending; meanwhile, NPL and LAR negatively affect bank lending in the long run. However, CAR does not significantly affect bank lending in the short run. On the other hand, OEOI negatively affects bank lending, and this result is following the hypothesis.

Assuming the asymmetric effect, in the short run NPL and OEOI negatively affect loan to deposit ratio when they increase. Meanwhile, LAR has a negative effect both when it increases and when it decreases, with a significant difference in the estimation coefficient. In the long run, the asymmetric effect can only be proven in the NPL effect. When NPLs increase, bank lending falls, but not in the opposite direction.

Banks must pay serious attention to indications of an increase in NPL and LAR and a decrease in CAR in the long run because it affects decreasing bank lending. In the long run, banks are consistent in observing indications of a possible increase in NPLs so that they can always take appropriate action in response to the resulting decrease in bank lending to maintain an ideal LDR in the range of 80 percent to 90 percent.

The banking supervisory agency, in this case, the financial services authority, needs to consistently supervise and enforce the effectiveness of regulations related to bank soundness, particularly those related to improving credit performance and strengthening the capital structure. In strengthening their role as financial intermediaries, banks also need to focus on efficiency to increase their ability to provide credit to borrowers.

This study has limitations because it uses time-series data with a method that is not able to sterilize the impact if it covers the current period due to the impact of the Covid-19 pandemic. Therefore, this research period is only limited to normal conditions until before the pandemic, so it does not cover any structural breaks in the time series.

This research was conducted on aggregate data and has not been carried out on bank-level data. Therefore, research with the same issue is needed but is based on banklevel data through a data panel so that results are obtained that corroborate the findings of this study. Future research can also include structural breaks by covering the period of the pandemic.

\section{REFERENCES}

Adzis, A. A., Sheng, L. E., \& Bakar, J. A. (2018). Bank lending determinants: Evidence from Malaysia commercial banks. Journal of Banking and Finance Management, 1(3), $36-48$.

Alkhazaleh, A. M. (2017). Factors may drive the commercial banks lending: Evidence from Jordan. Banks and Bank Systems, 12(2), 31-38. Retrieved from https:// doi.org/10.21511/bbs.12(2).2017.03

Al-Kilani, Q. A., \& Kaddumi, T. A. (2015). Cyclicality of lending behavior by banking sector for the period (2000-2013): Evidence from Jordan. International Journal of 
Economics and Finance, 7(4), 57-65. Retrieved from https:// doi.org/10.5539/ijef.v7n4p57

Arintoko, A. (2021). The stock price response of palm oil companies to industry and economic fundamentals. Journal of Asian Finance, Economics and Business, 8(3), 99-110. Retrieved from https://doi.org/10.13106/jafeb.2021.vol8.no3.0099

Asmara, E. N., \& Supardi. (2019). Determinant of credit distribution: Indonesian banking evidence. KnE Social Sciences, 3(26), 139-159. Retrieved from https:// doi.org/10.18502/kss.v3i26.5367

Atoi, N. V. (2018). Non-performing loan and its effects on banking stability: Evidence from national and international licensed banks in Nigeria. CBN Journal of Applied Statistics, 9(2), 43-74. Retrieved from https://doi.org/10.33429/Cjas.09218.3/6

Bahmani-Oskooee, M., \& Fariditavana, H. (2015). Nonlinear ARDL approach, asymmetric effects and the J-curve. Journal of Economic Studies, 42(3), 519-530. Retrieved from https:// doi.org/10.1108/JES-03-2015-0042

Baoko, G., Acheampong, I. A., \& Ibrahim, M. (2017). Determinants of bank credit in Ghana: A bounds-testing cointegration approach. African Review of Economics and Finance, 9(1), 33-61.

Bhattarai, B. P. (2020). Bank lending determinants: Evidence from Nepalese commercial banks. International Journal of Management, 11(10), 1-10. Retrieved from https:// doi.org/10.34218/IJM.11.10.2020.001

Cucinelli, D. (2015). The impact of non-performing loans on bank lending behavior: Evidence from the Italian banking sector. Eurasian Journal of Business and Economics, 8(16), 59-71. Retrieved from https://doi.org/10.17015/ejbe.2015.016.04

Duran, T., \& Duran, B. (2017). The effect of macroeconomic factors on credit to depositsratio (CDR): Evidencing Turkey. The Journal of International Social Research, 10(50), 684--704. Retrieved from https://doi.org/10.17719/jisr.2017.1702

Elliott, G., Rothenberg, T. J., \& Stock, J. H. (1996). Efficient tests for an autoregressive unit root. Econometrica, 64, 813-836. https://doi.org/10.2307/2171846

Havranek, T., Irsova, Z., \& Lesanovska, J. (2016). Bank efficiency and interest rate passthrough: Evidence from Czech loan products. Economic Modelling, 54, 153-169. Retrieved from https://doi.org/10.1016/j.econmod.2016.01.004

Isa, M. A., Latif, R. A., Zaharum, Z., Nasrul, F., \& Noh, M. K. (2019). Internal factors influencing commercial bank's lending behaviour in Malaysia. Advanced International Journal of Banking, Accounting and Finance, 1(1), 48-58. Retrieved from https:// doi.org/10.35631/aijbaf.11005

Iskandar, Y. (2017). The effect of non performing loans, operating expense to operating income, and loan to deposit ratio on stock return at conventional bank. Journal of Entrepreneur and Entrepreneurship, 6(1), 25-30. https:/ / doi.org/10.37715/jee.v6il.636

Kim, D., \& Sohn, W. (2017). The effect of bank capital on lending: Does liquidity matter? Journal of Banking $\mathcal{E}$ Finance, 77, 95-107. Retrieved from https://doi.org/10.1016/j.jbankfin.2017.01.011 
Mirzaei, A., \& Moore, T. (2019). Real effect of bank efficiency: Evidence from disaggregated manufacturing sectors. Economica, 86(341), 87-115. Retrieved from https:/ / doi.org/10.1111/ecca.12238

Miyajima, K. (2020). What influences bank lending in Saudi Arabia? Islamic Economic Studies, 27(2), 125-155. Retrieved from https://doi.org/10.1108/IES-07-2019-0018

Moradi, Z. S., Mirzaeenejad, M., \& Geraeenejad, G. (2016). Effect of bank-based or marketbased financial systems on income distribution in selected countries. Procedia Economics and Finance, 36, 510-521. Retrieved from https:// doi.org/10.1016/S22125671(16)30067-3

Moussa, M. A., \& Chedia, H. (2016). Determinants of bank lending: Case of Tunisia. International Journal of Finance and Accounting, 5(1), 27-36. Retrieved from https:// doi.org/10.5923/j.ijfa.20160501.04

Mujiatun, S., \& Handayani, S. (2018). Effect of operational cost and operational revenue on return on asset of sharia banking: Case study on sharia business division of PT. Bank Sumut. International Journal of Scientific \& Technology Research, 7(7), 223-227.

Naceur, S. B., Marton, K., \& Roulet, C. (2018). Basel III and bank-lending: Evidence from the United States and Europe. Journal of Financial Stability, 39, 1-27. Retrieved from https:// doi.org/10.1016/j.jfs.2018.08.002

Nguyen, H. D., \& Dang, V. D. (2020). Bank-specific determinants of loan growth in Vietnam: Evidence from the CAMELS approach. Journal of Asian Finance, Economics and Business, 7(9), 179-189. Retrieved from https:// doi.org/10.13106/jafeb.2020.vol7.no9.179

Nguyen, T., Tripe, D., \& Ngo, T. (2018). Operational efficiency of bank loans and deposits: A case study of Vietnamese banking system. International Journal of Financial Studies, 6(14), 1-13. Retrieved from https://doi.org/10.3390/ijfs6010014

Oyebowale, A. Y. (2020). Determintants of bank lending in Nigeria. Global Journal of Emerging Market Economies, 12(3), 378-398. Retrieved from https:// doi.org/10.1177/0974910120961573

Park, W., \& Min, B. (2021). Impacts of liquidity preference on loan-to-deposit ratio amd regional economic growth: A Post-Keynesian View. The Korean Economic Review, 37(1), 37-63. Retrieved from https:/ / doi.org/10.22841/kerdoi.2021.37.1.002

Polizzi, S., Scannella, E., \& Suárez, N. (2020). The role of capital and liquidity in bank lending: Are banks safer? Global Policy, 11(S1), 28-38. Retrieved from https:// doi.org/10.1111/1758-5899.12750

Prawitasari, D., Kadarningsih, A., Machmuddah, Z., \& Ud-din, M. (2020). Internal company factors as determining variables for improving bank lending. Journal of Asian Finance, Economics and Business, 7(8), 205-212. Retrieved from https:// doi.org/10.13106/jafeb.2020.vol7.no8.205

Qamruzzaman, M., \& Wei, J. (2018). Financial innovation, stock market development, and economic growth: An application of ARDL model. International Journal of Financial Studies, 6(69), 1-30. Retrieved from https:// doi.org/10.3390/ijfs6030069 
Rabab'ah, M. (2015). Factors affecting the bank credit: An empirical study on the Jordanian commercial banks. International Journal of Economics and Finance, 7(5), 166178. Retrieved from https:// doi.org/10.5539/ijef.v7n5p166

Sarath, D., \& Pham, D. V. (2015). The determinants of Vietnamese bank's lending behavior. Journal of Economic Studies, 42(5), 861-977. Retrieved from https:// doi.org/10.1108/JES-08-2014-0140

Shamshur, A., \& Weill, L. (2019). Does bank efficiency influence the cost of credit? Journal of Bank $\mathcal{E}$ Finance, 105, 63-73. Retrieved from https:// doi.org/10.1016/j.jbankfin.2019.05.002

Singh, S. K., Basuki, B., \& Setiawan , R. (2021). The effect of non-performing loan on profitability: Empirical evidence from Nepalese commercial banks. Journal of Asian Finance, Economics and Business, 8(4), 709-716. Retrieved from https:// doi.org/10.13106/jafeb.2021.vol8.no4.0709

Yasnur, M., \& Kurniasih, A. (2017). Factors affecting bank lending growth: Cases in Indonesia. International Journal of Scientific and Research Publications, 7(11), 69-76.

Zhu, N., Wang, B., \& Wu, Y. (2015). Productivity, efficiency and non-performing loans in the Chinese banking industry. The Social Science Journal, 52(4), 468-480. Retrieved from https:/ / doi.org/10.1016/j.soscij.2014.10.003

Zulkifli, S., Ali, M., \& Aswan , A. (2018). Analysis of factors affecting the loan to funding ratio at commercial banks listed on Indonesia stock exchange year 2011-2016. Hasanuddin Journal of Applied Business and Entrepreneurship, 1(2), 73-86. https:// doi.org/10.26487/hjabe.v1i2.81 